\title{
Purification and characterization of multisquamase, the prothrombin activator present in Echis Multisquamatus venom
}

Citation for published version (APA):

Petrovan, R. J., Govers-Riemslag, J. W. P., Nowak, G., Hemker, H. C., Rosing, J., \& Tans, G. (1997). Purification and characterization of multisquamase, the prothrombin activator present in Echis Multisquamatus venom. Thrombosis Research, 88(3), 309-316. https://doi.org/10.1016/S00493848(97)00258-2

Document status and date:

Published: 01/01/1997

DOI:

10.1016/S0049-3848(97)00258-2

Document Version:

Publisher's PDF, also known as Version of record

Please check the document version of this publication:

- A submitted manuscript is the version of the article upon submission and before peer-review. There can be important differences between the submitted version and the official published version of record.

People interested in the research are advised to contact the author for the final version of the publication, or visit the DOI to the publisher's website.

- The final author version and the galley proof are versions of the publication after peer review.

- The final published version features the final layout of the paper including the volume, issue and page numbers.

Link to publication

\footnotetext{
General rights rights.

- You may freely distribute the URL identifying the publication in the public portal. please follow below link for the End User Agreement:

www.umlib.nl/taverne-license

Take down policy

If you believe that this document breaches copyright please contact us at:

repository@maastrichtuniversity.nl

providing details and we will investigate your claim.
}

Copyright and moral rights for the publications made accessible in the public portal are retained by the authors and/or other copyright owners and it is a condition of accessing publications that users recognise and abide by the legal requirements associated with these

- Users may download and print one copy of any publication from the public portal for the purpose of private study or research.

- You may not further distribute the material or use it for any profit-making activity or commercial gain

If the publication is distributed under the terms of Article $25 \mathrm{fa}$ of the Dutch Copyright Act, indicated by the "Taverne" license above, 
REGULAR ARTICLE

Purification and Characterization of Multisquamase, the Prothrombin Activator Present in Echis Multisquamatus Venom

Ramona J. Petrovan ${ }^{1,2}$, José W.P. Govers-Riemslag', Götz Nowak ${ }^{2}$, H. Coenraad Hemker ${ }^{1}$, Jan Rosing' and Guido Tans' Cardiovascular Research Institute Maastricht, Department of Biochemistry, Maastricht University, Maastricht, The Netherlands; *Max-Planck-Gesellschaft, "Pharmacological Haemostaseology," Jena, Germany.

(Received 24 July 1997 by Editor K. Stocker; revised/accepted 6 September 1997)

\section{A bstract}

The venom of Echis multisquamatus (Central Asian sand viper) contains a single prothrombin activator, designated multisquamase, which is structurally and functionally different from ecarin, the prothrombin activator from the venom of Echis carinatus (sawscaled viper). Multisquamase is comprised of a $58000 \mathrm{Mr}$ and a $23000 \mathrm{Mr}$ subunit that consists of two disulfide-linked chains of $12000 \mathrm{Mr}$ and 10000 $\mathrm{Mr}$, respectively. In contrast to ecarin, which activates prothrombin and prethrombin 1 at comparable rates, and whose activity is hardly affected by $\mathrm{Ca}^{2+}$ or by changes in ionic strength, multisquamase hardly activates prethrombin 1 ; prothrombin activation requires $\mathrm{Ca}^{2+}$ and is strongly inhibited at high ionic strength. The most favourable kinetic parameters are observed at $1 \mathrm{mMCa}^{2+}$ and at low ionic strength $\left(\mathrm{K}_{\mathrm{m}}=0.085 \mu \mathrm{M}\right.$ and $\mathrm{k}_{\mathrm{cat}}=0.68 \mathrm{~s}^{-1}$ at $1 \sim 0.04)$. An increase in ionic strength considerably reduces the rate of prothrombin activation, due to an increase of the $\mathrm{K}_{\mathrm{m}}\left(\mathrm{K}_{\mathrm{m}}=0.8 \mu \mathrm{M}\right.$ and $\mathrm{k}_{\text {cat }}=1.03 \mathrm{~s}^{-1}$ at $\left.1 \sim 0.2\right)$. Studies in plasmas from patients on oral anticoagulant therapy show that

\footnotetext{
Abbreviations: PPACK, phenylalanyl-prolyl-arginine chloromethyl ketone; BCA, bicinchoninic acid; FPLC, fast protein liquid chromatography; INR, international normalized ratio; USP, U.S. Pharmacopoeia; BSA, bovine serum albumin.

Corresponding author: Dr. G. Tans, Dpt. Biochemistry, Maastricht University, P. 0. Box 616,6200 MD Maastricht, The Netherlands. Fax: 31-43-3670988; E-mail: <g.tans@bioch.unimaas.nl>.
}

E. Multisquamatus venom only activates carboxylated prothrombin, whereas E. carinatus activates both prothrombin and descarboxyprothrombin. Thus, multisquamase-dependent prothrombin activation appears to require post-translational modification of the gla-domain. This venom prothrombin activator may, therefore, become a useful tool to quantitate prothrombin and descarboxyprothrombin in cases where vitamin K-dependent carboxylation of prothrombin is impaired. (C) 1998 Elsevier Science Ltd.

Key Words: Snake venom; Prothrombin activation; Echis multisquamatus; Echis carinatus

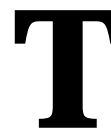
hrombin formation, one of the central reactions of blood coagulation, is the result of limited proteolysis of the zymogen prothrombin by blood coagulation factor Xa. Under physiological conditions, prothrombin activation is stimulated in a multiplicative way by the accessory components: $\mathrm{Ca}^{2+}$, negatively charged phospholipids and the protein cofactor, factor Va which together with factor $\mathrm{Xa}$ assemble in the so-called prothrombinase complex.

Prothrombin can also be activated by proteases present in snake venoms [1] from, amongst others, Australian Elapidae, Crotalidae, Viperidae, and Colubridae. Compared with factor Xa, venom activators can exhibit different mechanisms of prothrombin activation and requirements for cofac- 
tors. A well characterized and widely used prothrombin activator is ecarin [2,3], the metalloprotease present in Echis carinatus venom, that converts prothrombin exclusively into meizothrombin [4,5]. Ecarin not only activates prothrombin, but also prethrombin 1 and the descarboxy form of prothrombin [6-9]. Recently, Yamada et al. published the characteristics of a second prothrombin activator, callled carinactivase, present in the venom from Echis Carinatus, with properties different from those reported for ecarin [7].

Here we report the purification and characterization of the prothrombin activator from the venom of Echis multisquamatus.

\section{M aterials and $M$ ethods}

\subsection{Materials}

Hepes, Tris, EDTA, bovine serum albumin, and ovalbumin were purchased from Sigma Chemical Co. St. Louis, USA. The chromogenic substrates S2238 and S2366 were supplied by Chromogenix, Mdlndal, Sweden. Ecarin, the prothrombin activator from Echis carinatus venom was from Pentapharm, Basel, Switzerland. Crude Echis multisquamatus venom was from Latoxan, Rosans, France. Heparin (USP activity 175 units/mg) was from Leo Pharmaceuticals, Weesp, The Netherlands. Micro BCA protein assay kits were from Pierce, Rockford, USA. Immobilon-P membranes were from Millipore, Bedford MA 01730. Antibodies were from Kordia, Leiden, The Netherlands and Sigma Chemical Co. St. Louis, USA. Materials used for protein purification and the FPLC-system were from Pharmacia, Uppsala Sweden.

\subsection{Proteins}

Normal human plasma was obtained by collecting nine parts of blood from healthy volunteers in one part of $0.13 \mathrm{M}$ trisodium citrate $(\mathrm{pH} 7.8)$. The blood was centrifuged twice for 15 minutes at $3,000 \mathrm{Xg}$ at room temperature. Plasma from orally anticoagulated patients was a kind gift of Dr. Hamulyak (Dept. of Hematology, University Hospital, Maastricht). Human prothrombin was purified from fresh frozen plasma according to DiScipio et al. [10]. Prethrombin 1 was purified from a reaction mixture of human prothrombin with thrombin in $50 \mathrm{mM}$ Tris ( $\mathrm{pH} 7.9$ ), $175 \mathrm{mM} \mathrm{NaCl}$. After inhibi- tion of thrombin with PPACK, the reaction mixture was applied to a column (XK 5/10) with Q Sepharose fast flow. Prethrombin 1 did not adhere to the resin and fragment 1 , and non-cleaved prothrombin were eluted with a gradient of 250 to 600 $\mathrm{mM} \mathrm{NaCl}$. Human plasma, prothrombin, prethrombin 1 , fragment 1 , and purified venom activators were stored at $-80^{\circ} \mathrm{C}$. Protein preparations were homogeneous and $>95 \%$ pure as judged by SDS-PAGE according to Laemmli [11].

\subsubsection{Protein Concentrations}

Protein concentrations were determined with the micro BCA protein assay [12]. Prothrombin concentrations were determined after complete activation of prothrombin with Echis carinatus venom as described earlier [13].

\subsection{Methods}

\subsubsection{Prothrombin Activation}

Prothrombin activation was determined by measuring the generation of amidolytic activity towards chromogenic substrates (S2238 or S2366). Human prothrombin or prethrombin 1 was preincubated in a buffer containing $25 \mathrm{mM}$ Hepes ( $\mathrm{pH} 7.7$ ), 175 $\mathrm{mM} \mathrm{NaCl}$ at $37^{\circ} \mathrm{C}$. When divalent cations were present, these were included in the preincubation mixture. Activation was started by addition of appropriate dilutions of crude venom or purified venom activator in the same buffer. After different time intervals samples were withdrawn from the activation mixtures and transferred to cuvettes containing a final volume of $1 \mathrm{ml}$ of $50 \mathrm{mM}$ Tris- $\mathrm{HCl}$ (pH 7.9), $175 \mathrm{mM} \mathrm{NaCl}, 20 \mathrm{mM}$ EDTA, $0.5 \mathrm{mg} /$ $\mathrm{ml}$ ovalbumin, and $235 \mu \mathrm{M} \mathrm{S} 2238$ at $37^{\circ} \mathrm{C}$, and the amidolytic activity was quantitated as described earlier [14]. The amounts of activated prothrombin were calculated from a calibration curve made with known amounts of active site-titrated thrombin.

During purification, the activity of the venom activator was routinely assayed for prothrombin activation in reaction mixtures that contained 0.1 $\mu \mathrm{M}$ prothrombin, $3 \mathrm{mM} \mathrm{CaCl}_{2}$, and appropriate dilutions of the venom activator.

When plasma prothrombin was activated, the plasma was diluted 2000-fold in a buffer containing $25 \mathrm{mM}$ Hepes (pH 7.7), $175 \mathrm{mM} \mathrm{NaCl}, 1 \mathrm{mM} \mathrm{CaCl}_{2}$ and preincubated at $37^{\circ} \mathrm{C}$. Activation was started by addition of appropriate dilutions of crude venom in the same buffer. After different time intervals the amount of prothrombin activated was quanti- 
tated by measuring the generation of amidolytic activity towards S2366 on a SLT platereader set in the dual wavelength mode at $405-492 \mathrm{~nm}$. Since crude Echis multisquamatus venom shows a remarkably high amidolytic activity towards S2238, the activation of plasma prothrombin was quantitated with S2366 in these experiments.

\subsubsection{Kinetic Analysis}

Initial rates (v) of prothrombin or prethrombin 1 activation were determined at varying substrate concentrations $(S)$ and the kinetic parameters $K_{m}$ and Vmax were obtained by fitting the $\mathrm{v}$ vs. $\mathrm{S}$ curves to the Michaelis-Menten equation ( $\mathrm{V}=\mathrm{Vmax} \cdot \mathrm{S} /\left(\mathrm{K}_{\mathrm{m}}+\right.$ $\mathrm{S})$ using nonlinear least squares regression analysis.

\subsubsection{Gel Electrophoretic and Immunoblot Techniques}

Gel electrophoresis of the purified activator was carried out in the presence of SDS on 13\% slabgels [11] in a Miniprotean II cell from BioRad and the gels were stained with Coomassie Brilliant Blue $\mathrm{R}-250$. Products of prothrombin proteolysis in plasma were identified after SDS-PAGE on $10 \%$ slab gels, electrophoretic transfer of proteins from the gel to Immobilon-P membranes, and visualization with a monoclonal mouse-antibody directed against human prothrombin and anti-mouse IgG conjugated with alkaline phosphatase [15].

\section{Results}

\subsection{Purification of the Prothrombin Activator from Echis Multisquamatus}

The prothrombin activator present in the crude venom from Echis multisquamatus was purified by ion-exchange chromatography on Resource Q and Mono S at $\mathrm{pH}$ 7.5. The activator adhered to Resource $\mathrm{Q}$ and was eluted with a linear salt gradient (Fig. la) resulting in a purification of about 5-fold with a $76 \%$ yield (Table 1). Subsequent chromatography on Mono Q (Fig. lb) resulted in a further two-fold purification and a final overall yield of $13 \%$ (Table 1). SDS-PAGE on $13 \%$ slab gels (Fig. 2) showed that the purified activator contains two protein bands of 58000 and $23000 \mathrm{Mr}$, respectively, and that the 23000 band consisted of two polypetide chains held together by disulfide bond(s) as judged from the reduced sample (Fig. 2, lane 3). The activator eluted as a single symmetrical peak during gel permeation chromatography of Superdex-200 at $\mathrm{Mr}=67000$ (data not shown). Attempts to separate the two protein bands by incubation with 0.8 M NaSCN invariably resulted in complete loss of prothrombin converting activity. We conclude, therefore, that the purified activator is a two subunit enzyme. Furthermore, multisquamase likely is a metalloproteinase since treatment with EDTA $(0.1-$
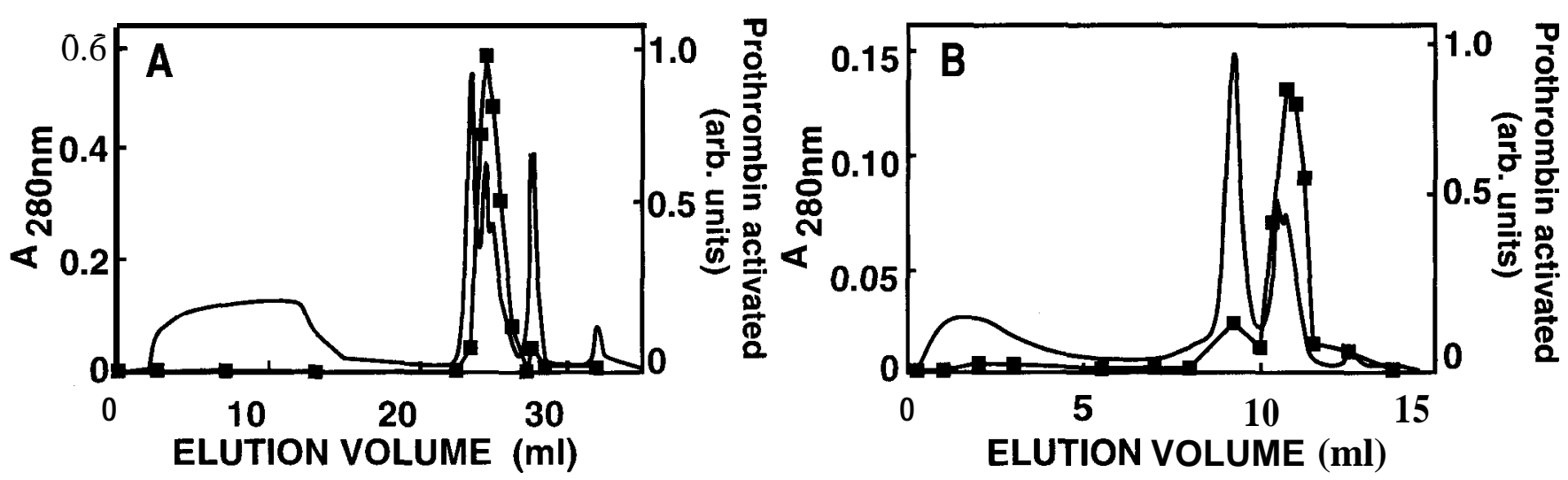

Fig. 1. Ion-exchange chromatography of the prothrombin activator from Echis multisquamatus. Panel A. 6 mg crude venom was dissolved in $22 \mathrm{ml}$ of $25 \mathrm{mM}$ Hepes $(\mathrm{pH} 7.5), 50 \mathrm{mM} \mathrm{NaCl}$, and $3 \mathrm{mM} \mathrm{CaCl}_{2}$, applied at a flow rate of 0.5 $\mathrm{ml} / \mathrm{min}$ to a $1 \mathrm{ml}$ Resource Q column and washed with $20 \mathrm{ml}$ startbuffer. Bound protein was eluted with a linear gradient of $2 \times 5 \mathrm{ml}(50 \mathrm{mM}$ to $500 \mathrm{mM} \mathrm{NaCl})$ in the same buffer. Protein was monitored by $\mathrm{A}_{280}$ (solid line) and fractions were tested for prothrombin activation ( $\mathbf{-}$ ) as decribed under "Material and Methods". Panel B. Prothrombin activatorcontaining fractions obtained after chromatography on Resource Q were pooled, diluted in $25 \mathrm{mM}$ Hepes (pH7.5), 3 $\mathrm{mM} \mathrm{CaCl}_{2}$ buffer to a final $\mathrm{NaCl}$ concentration of $50 \mathrm{mM}$, and applied to a $1 \mathrm{ml}$ Mono $\mathrm{S}$ column. The activator was eluted with a $2 \times 5 \mathrm{ml}$ linear gradient $(50 \mathrm{mM}$ to $500 \mathrm{mM} \mathrm{NaCl})$ in $25 \mathrm{mM}$ Hepes $(\mathrm{pH} 7.5), 3 \mathrm{mM} \mathrm{CaCl}_{2}$. 
Table 1. Purification of the prothrombin activator from Echis multisquamatus venom

\begin{tabular}{lccc}
\hline & \multicolumn{3}{c}{ Specific Activity } \\
& ( $\mathbf{m g})$ & $\begin{array}{c}\text { S } \\
\text { (nmol PT-activated/ } \\
\mathbf{~ m i n} / \boldsymbol{\mu g} \text { venom) }\end{array}$ & $\begin{array}{c}\text { R ecovery } \\
\mathbf{( \% )}\end{array}$ \\
\hline Crude venom & 5.21 & 0.22 & 100 \\
Resource Q & 0.78 & 1.11 & 76 \\
Mono S & 0.06 & 2.38 & 13 \\
\hline
\end{tabular}

Protein was determined with the micro BCA assay [12]. Prothrombin activation was determined as described under "Material and Methods." $\mathrm{PT}=$ prothrombin.

$0.3 \mathrm{mM}$ ) resulted in a rapid loss of prothrombin converting activity (data not shown). From the final specific activity obtained it appears that an unusually high percentage $(-9 \%)$ of the crude venom actually consists of prothrombin activator (Table 1).

\subsection{Prothrombin and \\ Prethrombin 1 Activation}

Rates of prothrombin and prethrombin 1 activation with purified activator were determined and compared to those obtained with ecarin, the prothrombin activator present in Echis carinatus venom. It was verified that time courses of prothrombin and prethrombin 1 activation were linear with time and proportional to the amount of enzyme present (data not shown). Table 2 summarizes the initial rates of activation of $1 \mu \mathrm{M}$ prothrombin or prethrombin 1 by $1 \mathrm{ng} / \mathrm{ml}$ ecarin or multisquamase. Prothrombin was activated some threefold faster by ecarin than by multisquamase. However, whereas ecarin activated prethrombin 1 and prothrombin at comparable rates, multisquamase was almost unable to activate prethrombin 1 whose rate of activation was approximately 500 fold slower than that of prothrombin (Table 2).

Figure 3 shows an experiment in which initial rates of $0.1 \mu \mathrm{M}$ prothrombin/prethrombin 1 activation by $4.5 \mathrm{ng} / \mathrm{ml}$ ecarin or $10 \mathrm{ng} / \mathrm{ml}$ multisquamase were determined at varying $\mathrm{NaCl}$ concentrations. Due to the fact that multisquamase-dependent prethrombin 1 activation was extremely slow the latter reaction was followed at a 50-fold higher concentration $(5 \mu \mathrm{M})$. At $30 \mathrm{mM} \mathrm{NaCl}$, ecarin was a somewhat better prothrombin activator than multisquamase but, as can be seen, both prothrombin and prethrombin 1 activation by multisquamase were strongly inhibited at higher ionic strength. Furthermore, at approximate physiological ionic strength, prothrombin activation by multisquamase was some 50-100 fold faster than prethrombin 1 activation. In constrast, ecarin-catalyzed activation of prothrombin or prethrombin 1 was much less affected by variation of the ionic strength and even at 400-500 mM $\mathrm{NaCl}$, prothrombin and prethrombin 1 activation occurred at $-40 \%$ of the rate observed at $30 \mathrm{mM}$ $\mathrm{NaCl}$ (Figure 3).

The kinetic parameters of prothrombin and prethrombin 1 activation by ecarin and multisquamase,

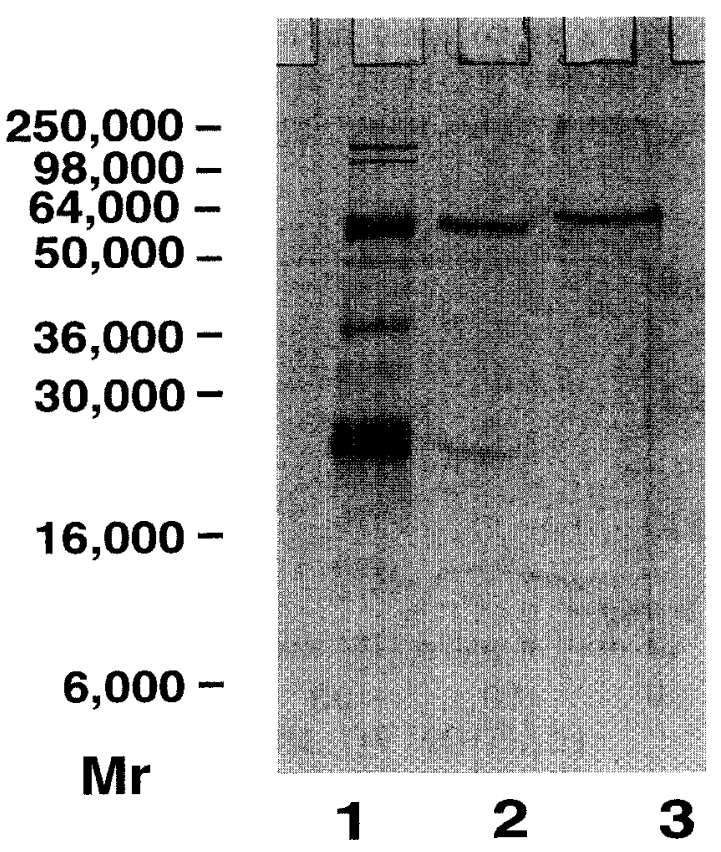

Fig. 2. SDS-PAGE of crude venom (lane 1) and purified activator (lanes 2-3) was carried out on 13\% slab gels according to Laemmli [11]. 5\% $\beta$-mercaptoethanol was present in the reduced sample (lane 3). The gels were stained with Coomassie Brilliant Blue R-250. Molecular weights of reference markers are indicated. 
Table 2. Rate of prothrombin and prethrombin 1 activation by ecarin and multisquamase

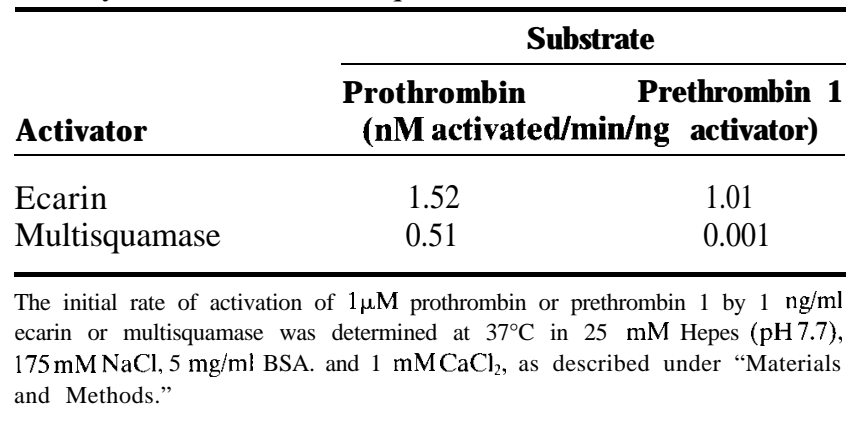

determined at $30 \mathrm{mM} \mathrm{NaCl}(\mathrm{I} \cong 0.04)$ and at $175 \mathrm{mM}$ $\mathrm{NaCl}(\mathrm{I} \cong 0.2)$, are summarized in Table 3. The Vmax of prothrombin and prethrombin 1 activation were minimally affected by an increase in the ionic strength. The low rate of prethrombin 1 activation by multisquamase is explained by its unfavourable $\mathrm{K}_{\mathrm{m}}$ which is approximately 200 -fold higher than the $\mathrm{K}_{\mathrm{m}}$ for prothrombin. It appeared that the inhibition observed for multisquamase at high ionic strength was mainly due to an increase of the $K$,. The $K_{m}$ for prethrombin 1 activation by multisquamase at high ionic srength was increased so much that it was impossible to obtain an accurate $\mathrm{K}_{\mathrm{m}}$ value (Table 3). It appears, therefore, that the interaction of multisquamase with prothrombin or prethrombin 1 is driven (at least for a major part) by electrostatic interactions and for efficient interaction to occur, the presence of fragment 1 is required.

However, prothrombin activation by multisquamase appears to be also strongly dependent upon the presence of $\mathrm{Ca}^{2+}$ as shown in Figure 4. Other metal ions known to induce the conformational change in prothrombin $\left(\mathrm{Mg}^{2+}\right.$ or $\mathrm{Mn}^{2+}$ but not $\left.\mathrm{Ba}^{2+}\right)$ [16] also stimulated multisquamase-catalyzed prothrombin activation (data not shown). In contrast, ecarin-dependent prothrombin or prethrombin 1 activation was hardly influenced by addition of divalent metal ions.

\subsection{Activation of Prothrombin and Descarboxyprothrombin by Ecarin and Multisquamase}

The above data strongly suggest that multisquamase not only requires an intact but also a carboxylated prothrombin molecule for efficient activation. To test this, prothrombin present in normal plasma and

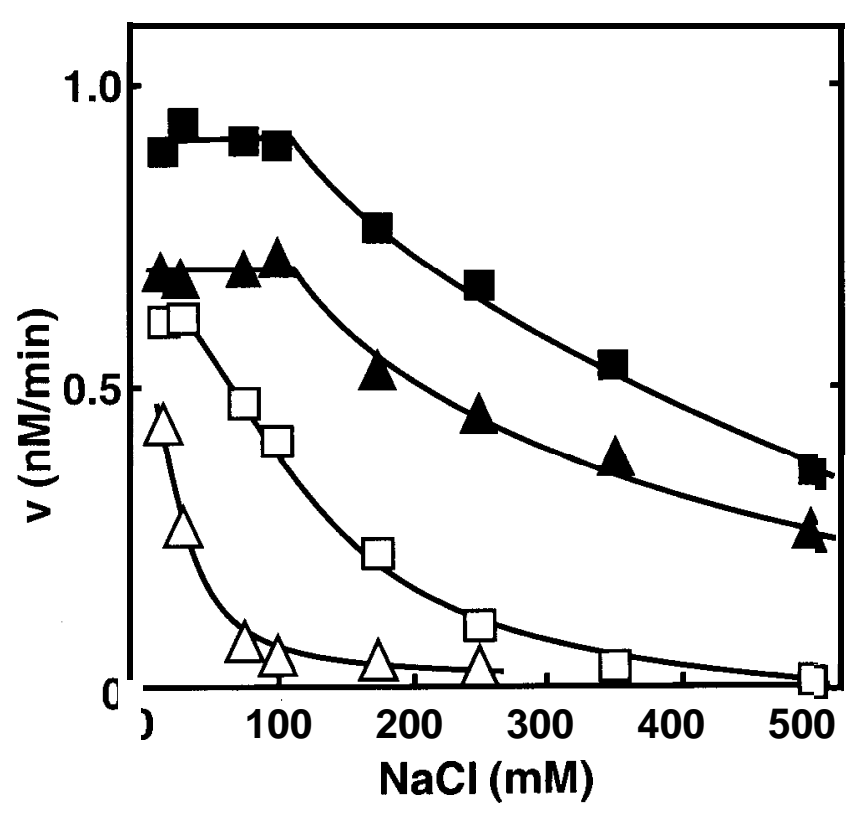

Fig. 3. Initial rates of prothrombin and prethrombin 1 activation by ecarin and multisquamase at varying $\mathrm{NaCl}$ concentrations. The rate of activation of $0.1 \mu \mathrm{M}$ prothrombin $(\square, \square)$ and of $0.1 \mu \mathrm{M}$ (A) or $5 \mu \mathrm{M}$ (A) prethrombin 1 by $4.5 \mathrm{ng} / \mathrm{ml}$ ecarin $(\boldsymbol{\square}, \mathbf{\Lambda})$ or $10 \mathrm{ng} / \mathrm{ml}$ multisquamase $(\square, \triangle)$ was determined as described under "Materials and Methods," at $37^{\circ} \mathrm{C}$ in reaction mixtures containing $25 \mathrm{mM}$ Hepes (pH 7.7), $1 \mathrm{mMCaCl}_{2}, 5 \mathrm{mg} / \mathrm{ml} \mathrm{BSA}$, and $\mathrm{NaCl}$ concentrations as indicated in the figure.

in plasma from a patient treated with vitamin $\mathrm{K}$ antagonists was activated with multisquamase. For comparison the same plasma samples were also activated with ecarin (ecarin activates prothrombin, prethrombin 1, and descarboxyprothrombin equally well [6-9]. The immunoblot presented in Figure 5 shows that both activators converted all prothrombin present in normal plasma and bands indicative for meizothrombin-des-fragment 1 and (meizo) thrombin-antithrombin III complexes became visible. In patient plasma, ecarin also activated all prothrombin and descarboxyprothrombin, but with multisquamase only part of the prothrombin present was converted. This indicates that multisquamase indeed only activated carboxylated prothrombin.

Thus, in principle the combination of prothrombin activation with ecarin and multisquamase should yield relevant information concerning the coagulant status of prothrombin present in a given plasma sample. Figure 6 shows the result of an experiment in which the prothrombin and descarboxyprothrombin present in a number of different plasma samples 
Table 3. Kinetic parameters of prothrombin and prethrombin 1 activation

\begin{tabular}{|c|c|c|c|c|}
\hline & \multicolumn{2}{|c|}{$30 \mathbf{m M} \mathbf{~ N a C l}$} & \multicolumn{2}{|c|}{$175 \mathrm{mM} \mathrm{NaCl}$} \\
\hline & $\underset{(\boldsymbol{\mu} \mathbf{M})}{\mathbf{K}_{\mathrm{m}}}$ & $\begin{array}{c}V_{\max } \\
\text { (nmol activated } \\
\mathrm{min} / \mu \mathrm{g} \text { act) }\end{array}$ & $\begin{array}{c}\mathbf{K}_{\mathbf{m}} \\
(\boldsymbol{\mu} \mathbf{M})\end{array}$ & $\begin{array}{c}V_{\max } \\
\text { (nmol activated } \\
\min / \mu \mathrm{g} \text { act) }\end{array}$ \\
\hline \multicolumn{5}{|l|}{ Ecarin } \\
\hline Prothrombin & 0.05 & 2.55 & 0.15 & 1.43 \\
\hline Prethrombin 1 & 0.03 & 1.55 & 0.12 & 1.01 \\
\hline \multicolumn{5}{|l|}{ Multisquamase } \\
\hline Prothrombin & 0.09 & 0.61 & 0.8 & 0.93 \\
\hline Prethrombin 1 & 22.92 & 1.11 & $>100$ & n.d. \\
\hline
\end{tabular}

$\mathrm{K}_{\mathrm{m}}$ and $\mathrm{V}_{\max }$ were obtained by fitting the Michaelis-Menten ( $\mathrm{v}$ vs. $\mathrm{S}$ ) curves using non-linear least squares regression analysis. kcat was calculated assuming a Mr of 55000 for ecarin [6] and 67000 for multisquamase (see Results). Final activation mixtures contained $25 \mathrm{mM}$ Hepes $(\mathrm{pH} 7.7), 1 \mathrm{mM} \mathrm{CaCl}_{2}, 5 \mathrm{mg} / \mathrm{ml} \mathrm{BSA}, 30$ or $175 \mathrm{mM} \mathrm{NaCl}$, appropriate dilutions of venom activators, and varying concentrations of prothrombin or prethrombin 1. n.d. $=$ not determined.

(randomly chosen from orally anticoagulated individuals, based on the INR values and independent of medical background) was activated with crude E. carinatus or with E. multisquamatus venom. Since multisquamase is the only prothrombin activator present in E. multisquamatus venom it is not necessary to isolate multisqamase from the crude venom for specific activation of prothrombin in a plasma sample. To yield accurate measurement of pro-

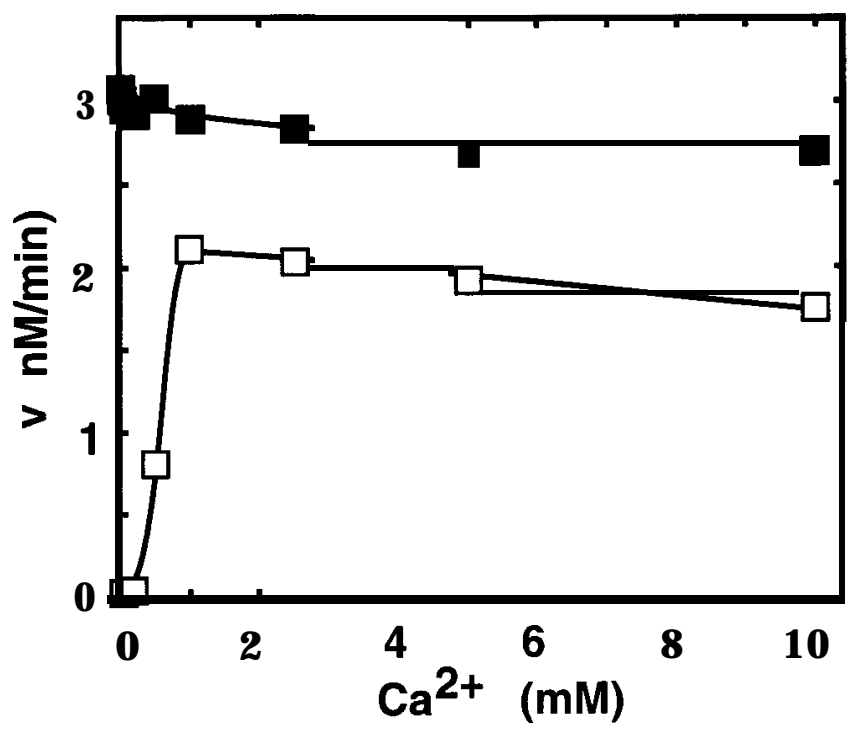

Fig. 4. Effect of $\mathrm{Ca}^{2+}$ on prothrombin activation by ecarin and multisquamase. Activation rates of $0.1 \mu \mathrm{M}$ prothrombin by $4.5 \mathrm{ng} / \mathrm{ml}$ ecarin $(\boldsymbol{\square})$ and $15 \mathrm{ng} / \mathrm{ml}$ multisquamase (0) were determined as described under "Materials and Methods", at $37^{\circ} \mathrm{C}$ in $25 \mathrm{mM}$ Hepes (pH 7.7), $5 \mathrm{mg} / \mathrm{ml} \mathrm{BSA}$, amounts of $\mathrm{Ca}^{2+}$ as indicated, and $\mathrm{NaCl}$ to yield a final ionic strength of 0.2 . thrombin levels (without interference of endogenous plasma inhibitors) the plasma samples were diluted 2000-fold before activation. A good correlation was observed when the ratio of the amidolytic activity obtained with E. carinatus (prothrombin plus descarboxyprothrombin) and with E. multisquamatus venom (prothrombin) was plotted against the INR value.

\section{Discussion}

The venom from the viper Echis multisquamatus contains a strong procoagulant which is capable of activating prothrombin. This procoagulant, which we call multisquamase, is a metalloproteinase that consists of two subunits of 58000 and $23000 \mathrm{Mr}$. The smaller subunit is comprised of two polypeptide chains linked together via a disulfide bridge.

The structural and functional properties of the E. multisquamatus activator are similar to those of carinactivase, a second prothrombin activator that was recently discovered to be present in the venom from E. carinatus [7]. However, the catalytic efficiency of multisquamase is not only dependent on the presence of $\mathrm{Ca}^{2+}$ but is also strongly affected by salt concentration. In addition, multisquamase is the only enzyme with prothrombin-converting activity present in the crude venom of $E$. multisquamatus. The fact that the crude venom did not activate prethrombin 1 at physiological ionic strength is indicative for the absence of an ecarin-like prothrombin activator in E. multisquamatus venom.

The catalytic efficiency of prothrombin activa- 


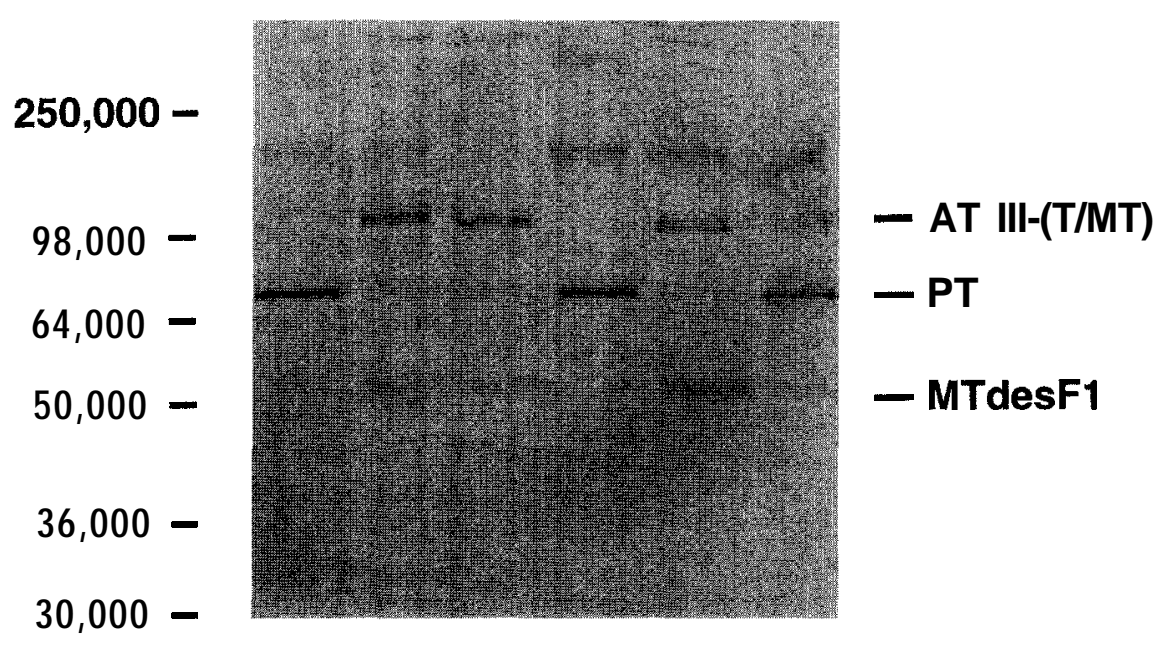

\section{$\begin{array}{lllllll}M r & 1 & 2 & 3 & 4 & 5 & 6\end{array}$}

Fig. 5. Immunoblot analysis of plasma prothrombin activation by ecarin and by the purified activator from E. multisquamatus. 40-fold dilutions of normal human plasma (lanes 1-3) and plasma from a patient on oral anticoagulant therapy (lanes 4-6) in a buffer containing $25 \mathrm{mM}$ Hepes ( $\mathrm{pH} 7.7), 175 \mathrm{mM} \mathrm{NaCl}, 1 \mathrm{mM} \mathrm{CaCl}_{2}$ were activated with ecarin or multisquamase to result in complete activation of prothrombin within $5 \mathrm{~min}$. After the amidolytic activity reached a constant level, 16 $\boldsymbol{\mu l}$ aliquots were subjected to SDS-PAGE (13\% gel) according to Laemmli [11]. Prothrombin and related products were visualized after transblotting to immobilon membranes and immunologic staining as described under "Materials and Methods." The relative positions of reference molecular weight markers are indicated. Lane 1, normal plasma; lane 2, normal plasma+ecarin; lane 3, normal plasma+multisquamase; lane 4, patient plasma; lane 5, patient plasma+ecarin; and lane 6 , patient plasma+multisquamase.

tion by multisquamase is rather high at low salt concentrations $\left(\mathrm{kcat} / \mathrm{K}_{\mathrm{m}} \cong 8 \times 10^{6}\right)$ and similar to that calculated for prothrombin and prethrombin 1 activation by ecarin at $175 \mathrm{mM} \mathrm{NaCl}$. However, at high salt concentrations the catalytic efficiency of multisquamase is decreased, due to an increase in the $\mathrm{K}_{\mathrm{m}}$ for prothrombin. Furthermore, $\mathrm{K}_{\mathrm{m}}$ for prethrombin 1 is extremely high and in fact could not be determined at physiological ionic strength which explains the observation that under these conditions multisquamase does not activate prethrombin 1 at appreciable rates.

These data demonstrate the importance of the fragment 1 region for efficient prothrombin activation by multisquamase. In addition divalent cations known to induce the conformational change in prothrombin are required for efficient activation. Thus, both crude E. multisquamatus venom and purified activator do not activate prethrombin 1 at $175 \mathrm{mM}$ $\mathrm{NaCl}$ and require the presence of a carboxylated fragment 1 region and the presence of $\mathrm{Ca}^{2+}$ for efficient prothrombin activation.

In contrast, the kinetic parameters of prothrom- bin or prethrombin 1 activation by ecarin are hardly affected by the reaction conditions and the enzyme does not show a similar requirement for the presence of $\mathrm{Ca}^{2+}$ and Gla residues.

The small pilot study, in which patient plasma prothrombin levels were determined both with the crude venoms from Echis carinatus and Echis multisquamatus, shows that the combination of these measurements correlated reasonably well with the INR values obtained for the individual plasma samples. These data indicate that Echis multisquamatus venom may be of future use as a tool to quantitate functional prothrombin in those cases where vitamin K-dependent carboxylation of prothrombin is hampered.

This work was supported by Program Grant 900-526-192 from the D utch 0 rganization for Scientific Research (NW O). R.J. Petrovan was supported by the Deutscher Akademischer Austauschdienst and Deutsche Akademie der Naturforscher "Leopoldina". We thank Dr. Hamulyak (Dept. of Hematology, University Hospital Maastricht) for donating the plasma samples of orally anticoagulated patients. 


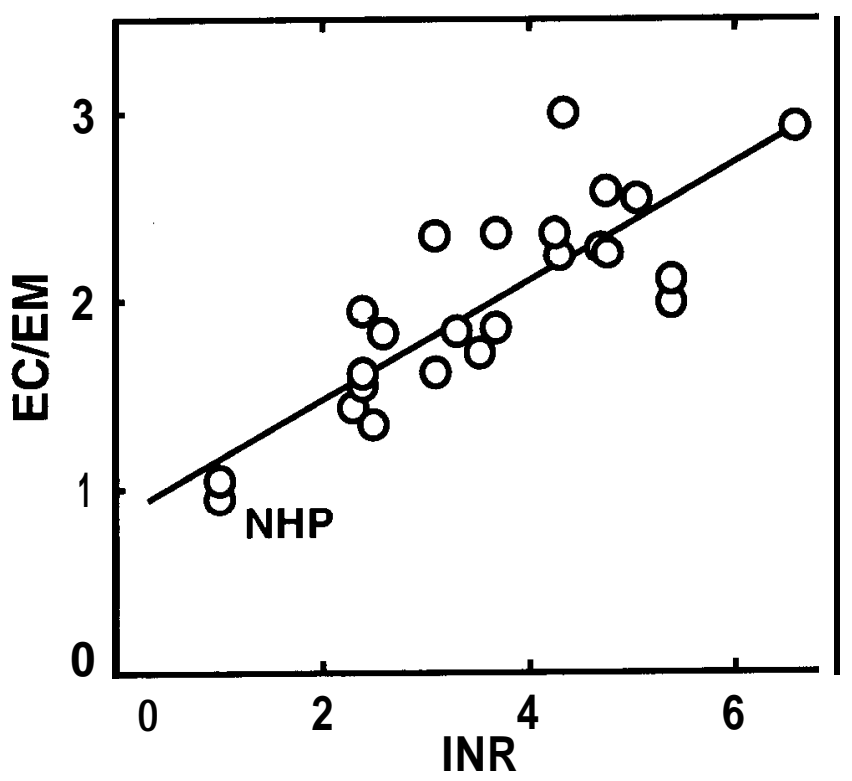

Fig. 6. Estimation of anticoagulation in plasma from orally anticoagulated patients. Plasma samples (diluted 1/2000) were activated with crude E. carinatus and E. multisquamatus venom. Amidolytic activity present after 30 minutes was determined using S2366 as a substrate, and the ratio of amidolytic activities formed by $\mathrm{E}$. carinatus and $\mathrm{E}$. multisquamatus (EC/EM) is plotted vs. the INR values. The solid line was obtained by linear regression analysis $(R=0.83)$. Further details are given under "Materials and Methods."

\section{R eferences}

1. Rosing J, Tans G. Inventory of exogenous prothrombin activators. Thromb Haemost 1991; 65:627-30.

2. Schieck A, Kornalik F, Habermann E. The prothrombin-activating principle from Echis carinatus venom. I. Preparation and biochemical properties. Naunyn-Schmiedeberg's Arch Pharmacol 1972;272:402-16.

3. Kornalik F, Blombäck B. Prothrombin activation induced by ecarin. A prothrombin converting enzyme from Echis carinatus venom. Thomb Res 1975;6:53-63.

4. Morita $\mathrm{T}$, Iwanaga $\mathrm{S}$. Prothrombin activator from Echis carinatus venom. Meth Enzymol 1981;80:303-11.

5. Rhee MJ, Morris S, Kosow DP. Role of meizothrombin and meizothrombin-(des F1) in the conversion of prothrombin to thrombin by the echis carinatus venom coagulant. Biochemistry 1982;21:3437-43.

6. Morita T, Iwanaga S. Purification and properties of prothrombin activator from the venom of echis carinatus. J Biochem 1978;83:559-70.

7. Yamada D, Sekiya F, Morita T. Isolation and characterization of carinactivase, a novel prothrombin activator in Echis carinatus venom with a unique catalytic mechanism. J Biol Chem 1996;271:5200-7.

8. Bergstrom K, Egberg N. Determination of vitamin $\mathrm{K}$ sensitive coagulation factors in plasma studies on three methods using synthetic chromogenic substrates. Thromb Res 1978;12: 531-47.

9. Kirchhof BRJ, Vermeer C, Hemker HC. The determination of prothrombin using synthetic chromogenic substrates choice of a suitable activator. Thromb Res 1978;13:219-32.

10. DiScipio RG, Hermodson MA, Yates SG, Davie EW. A comparison of human prothrombin; factor IX (Christmas factor), factor X (Stuart factor), and protein S. Biochemistry 1977; 16:698-706.

11. Laemmli UK. Cleavage of structural proteins during the assembly of the head of bacterophage t4. Nature 1970;227:680-5.

12. Smith PK, Krohn RI, Hermanson GT, Mallia AK, Gartner FH, Provenzano MD, Fujimoto EK, Goeke NM, Olson BJ, Klenk DC. Measurement of protein using bicinchoninic acid. Analyt Biochem 1985;150:76-85.

13. Tans G, Janssen Claessen T, Hemker HC, Zwaal RFA, Rosing J. Meizothrombin formation during factor Xa-catalyzed prothrombin activation: Formation in a purified system and in plasma. J Biol Chem 1991;266:21864-73.

14. Rosing J, Zwaal RFA, Tans G. Formation of meizothrombin as intermediate in factor $\mathrm{Xa}$ catalyzed prothrombin activation. J Biol Chem 1986;261:4224-8.

15. Blake MS, Johnston KH, Russell-Jones GJ, Gotschlich EC. A rapid, sensitive method for detection of alkaline phosphatase-conjugated anti-antibody on Western blots. Analyt Biochem 1984;136:175-9.

16. Nelsestuen GL. Role of gamma-carboxyglutamic acid: An unusual protein transition required for the calcium-dependent binding of prothrombin to phospholipid. J Biol Chem 1976;251:5648-56. 